\title{
Assessment of kitchen wastewater quality for irrigation
}

\author{
Rijwana Parwin $^{1} \cdot$ Kakoli Karar Paul ${ }^{1}[\mathbb{C}$
}

Received: 28 May 2019 / Accepted: 2 July 2020 / Published online: 13 November 2020

(C) The Author(s) 2020

\begin{abstract}
In this study, the potential reuse of kitchen wastewater (KWW) in irrigation was analyzed to reduce the present freshwater demand. To know the suitability of KWW for irrigation, the samples were first collected from an educational institute in India and then characterized according to its physical, chemical, and bacteriological properties. The characterized data were then compared with the standard limit for irrigation Food and Agriculture Organization (FAO in Water quality for agriculture. Irrigation and drainage paper 29, M56, 1994) and the US Salinity Laboratory (USSL). Apart from the above irrigation standards, the characterized data were also compared with sodium adsorption ratio (SAR), residual sodium carbonate, sodium percentage $(\mathrm{Na} \%)$, magnesium hazard $(\mathrm{MH})$, Kelly's ratio $(\mathrm{KR})$, and permeability index to get better clarity. From the characterization, it was found that carbonate, fluoride, chromium, and Escherichia coli were absent, whereas parameters like $\mathrm{pH}$, chloride, iron, copper, magnesium, lead, nickel, sodium, calcium, zinc, aluminum, and sodium adsorption ratio were within the permissible limit. The result obtained from the USSL classification system suggested that $30.77 \%$ of KWW samples are safe for irrigation. Moreover, its quality was found to be safe for irrigation based on SAR, Na\%, KR, and MH. For better decision making of KWW reuse in irrigation, the output of Mamdani fuzzy inference system (MFIS) was compared with the USSL classification system. The overall agreement between USSL and MFIS was found to be 55.6\% for KWW.
\end{abstract}

Keywords Fuzzy logic $\cdot$ Irrigation $\cdot$ Kitchen wastewater

\begin{tabular}{|c|c|}
\hline \multicolumn{2}{|c|}{ Abbreviations } \\
\hline BDL & Below detection limit \\
\hline $\mathrm{BOD}_{5}$ & Biochemical oxygen demand \\
\hline DO & Dissolved oxygen \\
\hline Ec & Electrical conductivity or salinity hazard \\
\hline KR & Kelly's ratio \\
\hline KWW & Kitchen wastewater \\
\hline $\mathrm{me} / \mathrm{L}$ & Milliequivalent per liter \\
\hline $\mathrm{mg} / \mathrm{L}$ & Milligram per liter \\
\hline MH & Magnesium hazard \\
\hline $\mathrm{Na} \%$ & Sodium percentage \\
\hline NTU & Nephelometric turbidity units \\
\hline PI & Permeability index \\
\hline RSC & Residual sodium carbonate \\
\hline SAR & Sodium adsorption ratio \\
\hline TDS & Total dissolved solid \\
\hline TS & Total solid \\
\hline TSS & Total suspended solid \\
\hline
\end{tabular}

Kakoli Karar Paul

k_karar1@yahoo.co.in

1 Department of Civil Engineering, NIT, Rourkela 769008, India

$\begin{array}{ll}{ }^{\circ} \mathrm{C} & \text { Degree Celsius } \\ \% & \text { Percent } \\ \mu \mathrm{s} / \mathrm{cm} & \text { Microsiemens per centimeter } \\ \mu \mathrm{g} / \mathrm{L} & \text { Microgram per liter } \\ > & \text { Greater than } \\ < & \text { Less than }\end{array}$

\section{Introduction}

Rapid urbanization and industrialization raise the continuous demand for freshwater supply (Amiri et al. 2014; Parwin et al. 2017). But the limited availability of freshwater resource demands treated wastewater as a substitute for the non-potable use. Wastewater can be considered as both resource and hazard (Hussain et al. 2002). Wastewater is a vital source of essential nutrients and organic matter (Parwin and Paul 2020). According to Shakir et al. (2017), domestic sewage contains a proportion of organic matter and harmful microorganisms such as bacteria, virus, and protozoan, thus causing typhoid, dysentery, diarrhea, and vomiting due to contamination of freshwater. Reuse of wastewater will reduce environmental pollution and supply 
cost and abstain from contaminating freshwater (Al-Jayyousi 2003; Al-Hamaiedeh and Bino 2010). But it consisted of unwanted chemicals and harmful pathogens that can cause both environmental and health risks. The untreated wastewater use in irrigation increases due to water scarcity and inappropriate and insufficient wastewater treatment and disposal and reduces fertilizer costs (Scott et al. 2004; Qadir et al. 2007; Jimenez and Asano 2008). According to Jimenez (2006), wastewater reuse for irrigation can have positive and negative effects. The positive effects are increasing in food production due to nutrients and less investment due to wastewater use, whereas negative effects are health risk via consumption of pathogens and toxic chemicals through plants. According to FAO (1994), irrigation water with excess ionic concentrations can cause plant toxicity and consumption of such causes a serious health hazard. Wastewater causes land salinity and sealing of land and thus causes increased runoff and land erosion (Halliwell et al. 2001; Shakir et al. 2017). Therefore, it is a challenging situation to identify a proper reuse option for agriculture and other sectors with proper utilization of nutrients in it (Raychaudhuri et al. 2014).

Every day, millions of gallons of wastewater are produced from various domestic and industrial activities worldwide (Parwin and Paul 2018, 2019a, b). Black wastewater (including toilet waste) and gray wastewater (excluding toilet waste) are two types of domestic wastewater. The gray wastewater consists of $80 \%$ of the total wastewater generation with a maximum contribution (44\%) from the kitchen (Vakil et al. 2014). Production of kitchen wastewater (KWW) remains constant irrespective of weather or seasonal variation. The waste produced from kitchen outlet plays a vital role in producing a large volume of organic waste, oil-grease (stick inside the pipe and clogs the pipes), and soap-detergents from educational intuitions, professional organizations, and restaurants (Chandekar and Godboley 2017). In developing countries, KWW with high organic matter and oil and grease was disposed into water bodies without treatment (Naserisafavi and Chu 2017; Rahmat et al. 2017; Gupta and Nath 2018; Katam and Bhattacharyya 2018; Mohamed et al. 2018). Untreated disposal of KWW can cause eutrophication in the water body. Also, the stagnant KWW can become anoxic and create unpleasant odors by the release of ammonia and provide a breeding environment for insect pests. The characteristics of KWW can vary due to the type of cooking and nutritional preferences among households (Mohamed et al. 2013). There is a need for detailed characterization that may help in selecting its optimized treatment method to reduce the impact on soil, crop, and environment.

Agriculture is the major consumer of freshwater in India. Very few research works have been focused on irrigation water from KWW (Ghosh et al. 2010; Khan et al. 2011; Abegunrin et al. 2013; Sivarajah and Gnanavelrajah 2015;
Abubakar et al. 2016). As KWW is rich in nutrients, still it remains unnoticed from a quality perspective for irrigation. There are various standards available such as US Salinity Laboratory (USSL) classification system (1954), Wilcox system (1955), and BIS classification system (BIS 11624:1986) to understand the requirement of irrigation water quality. But still, uncertainties arise in the decision making with respect to the usefulness of water particularly when it is wastewater. Few researchers have applied fuzzy logic to solve the complex environmental problem. The concept of fuzzy logic has been applied by several researchers to attain at a simple output (Jowitt and Lumbers 1982; Mirabbasi et al. 2008; Priya 2013; Ostovari et al. 2015; Srinivas and Singh 2017). Adaptive-network-based fuzzy inference system (ANFIS) for irrigation water quality has been applied by Alavi et al. (2010). There is a need for a simple output from the set of complex input variables. Kizhisseri and Mohamed (2016) applied successfully the fuzzy logic concept-based wastewater quality indices for pollution classification. The objective of present study is to characterize the KWW samples to know the hidden characteristics. After obtaining the physicochemical parameters, the reuse possibility of KWW in irrigation needs to be explored. To simplify the decision making process of KWW reuse in irrigation, fuzzy logic approach needs to be applied on the physicochemical parameters.

\section{Materials and methods}

\section{Sample collection and data analysis}

The KWW samples were collected from a hostel of National Institute of Technology (NIT) Rourkela in India with capacity of more than 1000 students. A total of 13 number of wastewater samples (including both working days and holiday) were collected for characterization. The sampling was done in three shifts, i.e., morning, afternoon, and evening separately. Plastic bottles of $5 \mathrm{~L}$ and $2 \mathrm{~L}$ capacity were used to collect the wastewater samples. The plastic bottles were thoroughly cleaned by tap water, washed with Millipore water, and again rinsed by KWW sample to avoid any contamination. The collected samples were analyzed for physical, chemical, and bacteriological parameters using different standards, methods, and instruments listed in Table 1. The collected samples were tested in the Environmental Engineering Laboratory of Civil Engineering Department of NIT Rourkela. Metallic concentrations were measured by atomic absorption spectrophotometer (AAS 200, PerkinElmer). Each test conducted triplicates. The estimation of the indices such as sodium adsorption ratio (SAR) using Richards (1954) equation, sodium percentage ( $\mathrm{Na} \%)$, residual sodium carbonate (RSC), magnesium hazard (MH) and permeability 
Table 1 Experimental procedure for characterization of kitchen wastewater

\begin{tabular}{|c|c|c|c|}
\hline Parameters & Standards adopted & Methods used for estimation & Instrument used for estimation \\
\hline Sampling & IS:3025 (Part 1): 1998 & - & - \\
\hline Color & - & - & Eye observation \\
\hline Odor & - & - & Olfactory sense \\
\hline Temperature $\left({ }^{\circ} \mathrm{C}\right)$ & - & - & HQ40D (HACH) \\
\hline $\mathrm{pH}$ & - & - & HQ40D (HACH) \\
\hline Turbidity (NTU) & - & - & $2100 \mathrm{Q}(\mathrm{HACH})$ \\
\hline Total hardness (mg/L) & IS:3025 (Part 21):2009 & EDTA method & - \\
\hline DO (mg/L) & IS:3025 (Part 38): 2003 & Winkler method & - \\
\hline Chloride (mg/L) & IS:3025 (Part 32): 2003 & Argentometric method & - \\
\hline $\mathrm{BOD}_{5}(\mathrm{mg} / \mathrm{L})$ & IS:3025 (Part 44): 2003 & Dilution technique & BOD incubator (REICO) \\
\hline Fluoride (mg/L) & IS:5182 (Part 13): 2003 & Zirconium SPADNS method & $\begin{array}{l}\text { UV/Vis spectrometers, } \\
\text { PerkinElmer Lambda } 35\end{array}$ \\
\hline $\begin{array}{l}\mathrm{Fe}, \mathrm{Cu}, \mathrm{Mg}, \mathrm{Pb}, \mathrm{Ni}, \mathrm{Na}, \mathrm{Ca}, \mathrm{K}, \mathrm{Zn}, \mathrm{Cr} \\
\quad \mathrm{Al}(\mathrm{mg} / \mathrm{L})\end{array}$ & $\begin{array}{l}\text { IS:3025 (Part 53,42,46,47,54,45,4 } \\
0,45,49,52,55): 2003\end{array}$ & - & AAS200 PerkinElmer \\
\hline Arsenic $(\mu \mathrm{g} / \mathrm{L})$ & IS:3025 (Part 37):2003 & - & HGA 900-AAS 200 \\
\hline Mercury $(\mu \mathrm{g} / \mathrm{L})$ & IS:3025 (Part 48): 2003 & - & MHS15-AAS 200 \\
\hline TS, TDS, TSS (mg/L) & IS:3025 (Part 15,16,17): 2009 & Gravimetric method & Hot air oven (REICO) \\
\hline Sulfate $(\mathrm{mg} / \mathrm{L})$ & IS:3025 (Part 24): 2003 & Turbidity method & $\begin{array}{l}\text { UV/Vis spectrometers, } \\
\text { PerkinElmer Lambda } 35\end{array}$ \\
\hline Carbonate and bicarbonate $(\mathrm{mg} / \mathrm{L})$ & IS:3025 (Part 51): 2001 & Titrimetric method & - \\
\hline Phosphate (mg/L) & $\begin{array}{l}\text { 4500-P. D } \\
\text { APHA (2012) }\end{array}$ & Stannous chloride method & $\begin{array}{l}\text { UV/Vis spectrometers } \\
\text { PerkinElmer Lambda } 35\end{array}$ \\
\hline E. coli & - & EMB agar method & $\begin{array}{l}\text { Laminar air flow (REICO) and } \\
\text { incubator (REICO) }\end{array}$ \\
\hline
\end{tabular}

index (PI) using Houatmia et al. (2016) equation, and Kelly's ratio (KR) using Kelly (1963) equation was performed.

\section{USSL diagram for irrigation water quality evaluation}

USSL diagram is a well-known diagram for classifying irrigation water quality. It was suggested by US Salinity Laboratory Staff (1954). The USSL diagram is a simple scatter plot of salinity hazard (Ec) on $X$-axis against sodium hazard (SAR) on $Y$-axis. The salinity hazard (Ec) is plotted on a log scale. USSL classified water into the following classes (Table 2).

\section{Fuzzy interference system (FIS)}

In 1965, Zadeh introduced the concept of the fuzzy set to establish a soft boundary between different levels of subjects where membership is defined by degree. A FIS consists of knowledge base, fuzzifier, inference system (engine), and defuzzifier (Alavi et al. 2010). Researchers (Mirabbasi et al. 2008; Gharibi et al. 2012; Priya 2013; Ostovari et al. 2015) proved fuzzy logic to be a comprehensive tool for the assessment of water quality. In this study, Mamdani fuzzy inference system (MFIS) has been formulated using a fuzzy logic toolbox of MATLAB R2014b software. Membership functions were allocated for two input variables (Ec and SAR), and one output variables of MFIS called kitchen wastewater irrigation score (KWWIS) were used to classify KWW quality. The value for SAR classes, Ec classes and KWWIS classes and rules $16(4 \times 4)$ were taken from Mirabbasi et al. (2008) and Ostovari et al. (2015). Further, $16(4 \times 4)$ rules were formulated as shown in Fig. 1.
Table 2 Classification of irrigation water

\begin{tabular}{|c|c|c|c|c|c|}
\hline SAR value (me/L) & Class & Suitability & Ec value $(\mu \mathrm{S} / \mathrm{cm})$ & Class & Suitability \\
\hline$<10$ & $\mathrm{~S}_{1}$ & Very good & $<250$ & $\mathrm{C}_{1}$ & Very good \\
\hline 10-18 & $\mathrm{S}_{2}$ & Good & $250-750$ & $\mathrm{C}_{2}$ & Good \\
\hline $18-26$ & $\mathrm{~S}_{3}$ & Satisfactory & $750-2250$ & $\mathrm{C}_{3}$ & Satisfactory \\
\hline$>26$ & $\mathrm{~S}_{4}$ & $\mathrm{Bad}$ & $>2250$ & $\mathrm{C}_{4}$ & $\mathrm{Bad}$ \\
\hline
\end{tabular}


Fig. 1 Fuzzy logic interference system (rule viewer)
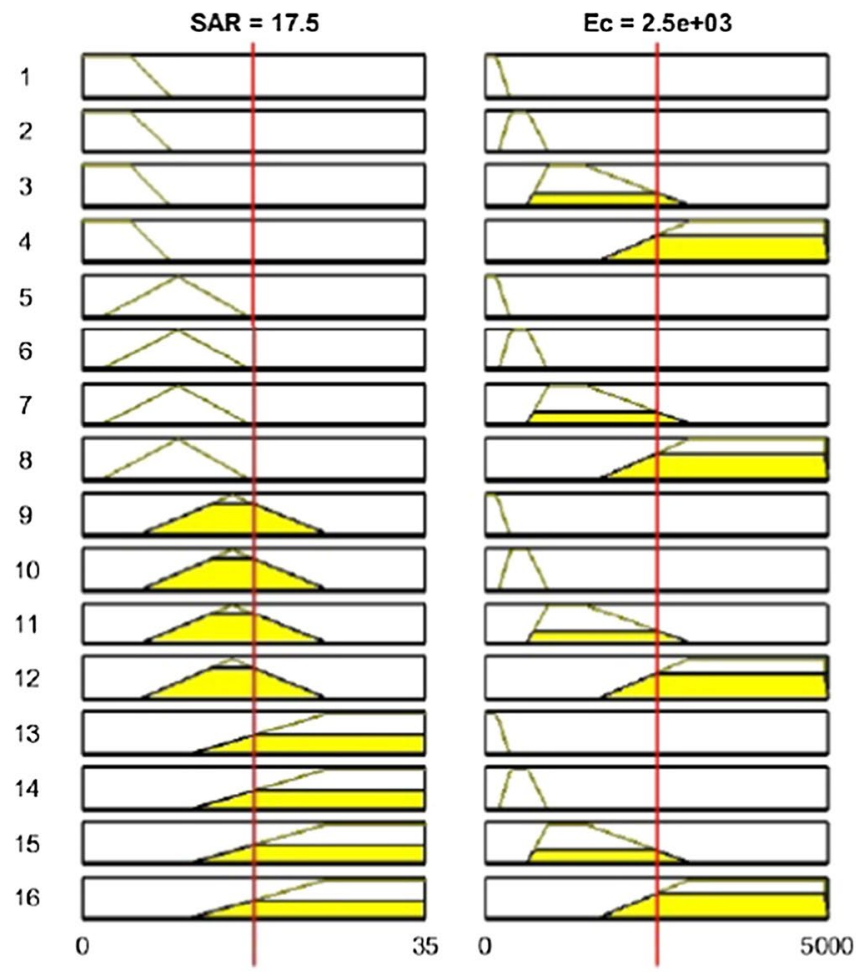

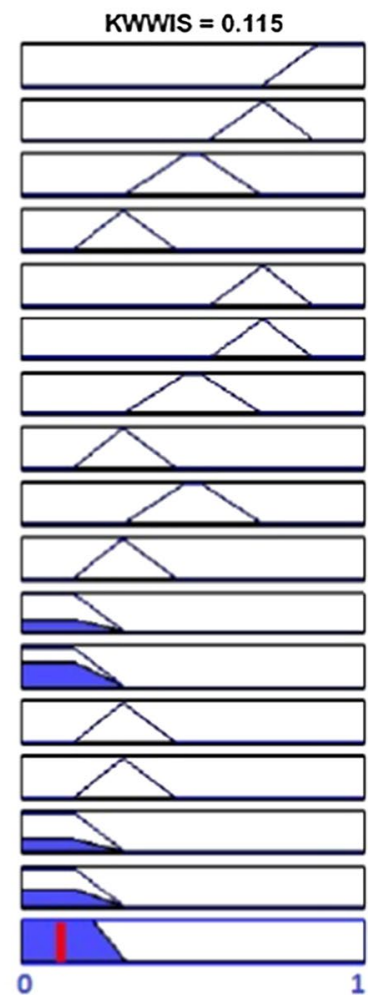

\section{Results and discussion}

In the present study, a detailed characterization of raw KWW collected from educational institute was performed to check its suitability for irrigation use. The bacteriological test showed the absence of Escherichia coli (E. coli) in KWW samples. The characterized data were then compared with the prescribed limit of Food and Agriculture Organization (FAO 1994). Carbonate, chromium, and fluoride were not found in the sample. The $\mathrm{pH}$ values were found within the permissible limit, while TDS and Ec concentration exceeded the standard limit (Table 3). A higher value of TDS is due to washing of plates and utensils that contain sticking food waste. A higher value of TDS can hamper disinfection, clogging of irrigation systems, and deposition (FAO 1994). A significantly higher value of $\mathrm{BOD}_{5}$ of $\mathrm{KWW}$ indicated a large amount of biodegradable organic materials.

According to FAO (1994), irrigation water with excess ionic concentrations can cause plant toxicity. All trace elements are not lethal, but in small concentration, many trace elements are essential for plant growth like Fe, and $\mathrm{Zn}$ and excess concentration will cause undesirable accumulations in plant tissue (FAO 1994). Potassium plays an essential role in photosynthesis and metabolism of plants. The study found $\mathrm{pH}$, chloride, iron, copper, magnesium, lead, nickel, sodium, calcium, zinc, aluminum, and sodium adsorption ratio (SAR) are within permissible limit, while bicarbonate, total dissolved solid, conductivity, sulfate, and potassium have exceeded the permissible limit. The extremely hard water consumption for long term might lead to increased probability of cardiovascular disorders and urolithiasis (Houatmia et al. 2016). The range of total hardness in KWW samples varies from 125 to $450 \mathrm{mg} / \mathrm{L}$ with an average value of $221.92 \mathrm{mg} / \mathrm{L}$. Sulfate is also an important anion that causes a laxative effect on the human physiological system (Houatmia et al. 2016). Its concentration was obtained from 15.80 to $2206.66 \mathrm{mg} / \mathrm{L}$ with a mean value of $1245.59 \mathrm{mg} / \mathrm{L}$ that exceeded the limit of irrigation limit $(960 \mathrm{mg} / \mathrm{L})$. Chloride value varies from 159.52 to $1985.20 \mathrm{mg} / \mathrm{L}$ with an average value of $934.52 \mathrm{mg} / \mathrm{L}$ and is found within the acceptable limit (1062 mg/L) of FAO (1994) guideline.

Sridharan and Nathan (2017) analyzed the groundwater quality for irrigation use using SAR, magnesium adsorption ratio (MAR), $\mathrm{RSC}, \mathrm{Na} \%, \mathrm{PI}$, and chlorinity index. Nagaraju et al. (2016) evaluated the groundwater quality for irrigation purpose using salinity hazard, potential salinity, total hardness, total alkalinity, non-carbonate hardness, sodium hazard, and carbonate and bicarbonate hazard. Houatmia et al. (2016) evaluated SAR, Na\%, RSC, KR, MH, and PI for groundwater quality for irrigation. The KWW contains essential dissolved minerals like surface water and groundwater. Its suitability for irrigation purpose needs great attention as the crop productivity depends on the quality of irrigation water.

The SAR is used for evaluating the suitability of wastewater for irrigation as it measures alkali/sodium hazard to 
Table 3 Summary of KWW quality parameters compared to standard guidelines

\begin{tabular}{|c|c|c|c|c|c|}
\hline Parameters & Mean* & Range & $\begin{array}{l}\text { Usual range in irrigation } \\
\text { water FAO (1994) }\end{array}$ & $\begin{array}{l}\text { Discharge into } \\
\text { public sewer } \\
\text { (IS:2490, 1981) }\end{array}$ & $\begin{array}{l}\text { Discharge into } \\
\text { Inland surface } \\
\text { waters } \\
\text { (IS:2490, 1981) }\end{array}$ \\
\hline $\mathrm{pH}$ & 6.43 & $5.42-7.2$ & $6.5-8.4$ & $5.5-9$ & $5.5-9$ \\
\hline Temperature $\left({ }^{0} \mathrm{C}\right)$ & 28.65 & $24.3-34.6$ & - & 45 & 40 \\
\hline Turbidity (NTU) & 1130.38 & $111-3129$ & - & - & - \\
\hline Total hardness (mg/L) & 221.92 & $125-450$ & - & - & - \\
\hline Total solid (mg/L) & 6005 & $2394-16215$ & - & - & - \\
\hline Total suspended solid (mg/L) & 2353 & $316-7705$ & - & 600 & 100 \\
\hline Total dissolved solid (mg/L) & 3652 & $936-8510$ & $450-2000$ & 2100 & 2100 \\
\hline Electrical conductivity $(\mu \mathrm{S} / \mathrm{cm})$ & 5450.75 & $1397.01-12,701.49$ & $700-3000$ & - & - \\
\hline Bicarbonate $(\mathrm{mg} / \mathrm{L})$ & 664.62 & $200-1300$ & 610 & - & - \\
\hline Carbonate (mg/L) & $\mathrm{BDL}^{* *}$ & - & 3 & - & - \\
\hline Chloride (mg/L) & 934.52 & $159.52-1985.2$ & 1062 & 1000 & 1000 \\
\hline Fluoride (mg/L) & $\mathrm{BDL}^{* *}$ & - & 1 & 15 & 2 \\
\hline Sulfate (mg/L) & 1245.59 & $15.8-2206.66$ & 960 & 1000 & 1000 \\
\hline DO (mg/L) & 3.31 & $1.01-5.62$ & - & - & - \\
\hline $\mathrm{BOD}_{5}(\mathrm{mg} / \mathrm{L})$ & 698.46 & $240-1340$ & - & 350 & 30 \\
\hline Iron (mg/L) & 0.17 & $0.04-0.56$ & 5 & - & - \\
\hline Copper (mg/L) & 0.01 & $0.001-0.033$ & 0.2 & 3 & 3 \\
\hline Magnesium (mg/L) & 3.38 & $3.14-4.10$ & 60.75 & - & - \\
\hline Lead (mg/L) & 0.09 & $0.011-0.168$ & 5 & 1 & 0.1 \\
\hline Nickel (mg/L) & 0.02 & $0.008-0.048$ & 0.2 & 3 & 3 \\
\hline Sodium (mg/L) & 5.69 & $3.45-7.61$ & 920 & - & - \\
\hline Calcium (mg/L) & 16.58 & $12.88-20.53$ & 400 & - & - \\
\hline Potassium (mg/L) & 2.32 & $1.12-4.05$ & 2 & - & - \\
\hline Zinc (mg/L) & 0.96 & $0.039-2.048$ & 2 & 15 & 5 \\
\hline Chromium (mg/L) & $\mathrm{BDL}^{* *}$ & - & 0.1 & 2 & 2 \\
\hline Aluminum (mg/L) & 0.07 & $0.016-0.207$ & 5 & - & - \\
\hline Phosphate (mg/L) & 1.29 & $0.081-3.089$ & 2 & - & 5 \\
\hline Mercury ( $\mu \mathrm{g} / \mathrm{L})$ & 10.41 & $0.177-34.09$ & - & 10 & 10 \\
\hline Arsenic $(\mu \mathrm{g} / \mathrm{L})$ & 2.9 & $0.536-4.947$ & 100 & 200 & 200 \\
\hline $\mathrm{SAR}(\mathrm{me} / \mathrm{L})$ & 0.329 & $0.19-0.46$ & 15 & - & - \\
\hline
\end{tabular}

*Mean value of $n=13,{ }^{* *}$ BDL-below detection limit

crops. In this study, the SAR value ranges from 0.19 to 0.46 (Fig. 2). Excessive sodium concentration in a water sample can have adverse effects in soil permeability (Shakir et al. 2017). The concentration of sodium is a vital parameter in categorizing for its use in irrigation. It affects both soil permeability and infiltration rate. Its excess concentration in irrigation water deteriorates the structure of the soil and thus reduces crop production. High sodium concentration will be adsorbed by clay particles displacing magnesium and calcium ions in soil and thus reduces the soil permeability and finally results in poor internal drainage in soil (Ravikumar and Somashekar 2014).

Water sample containing carbonate plus bicarbonate greater than calcium plus magnesium concentration is called residual sodium carbonate (RSC). The RSC is used to designate the alkalinity hazard of irrigation water for clay soils having high cation exchange capacity. When sodium in water is high in comparison with magnesium and calcium, clay soil swells, undergoes dispersion, and reduces its infiltration capacity. The RSC values vary from 2.06 to $20.40 \mathrm{me} / \mathrm{L}$. From the observed results, only two of the KWW samples are categorized as marginally suitable for agricultural use.

The KR value $>1$ indicates excess sodium concentration in water. So, water with $\mathrm{KR}<1$ is suitable for irrigation, while those with a ratio $>1$ are unsuitable. The KR is used to estimate the harmful effect of sodium on irrigation water quality. It ranges from 0.12 to 0.32 . All wastewater samples are suitable for irrigation use, which have a KR 
Fig. 2 Variation of SAR, Na, RSC, KR, MH, PI among KWW samples
SAR

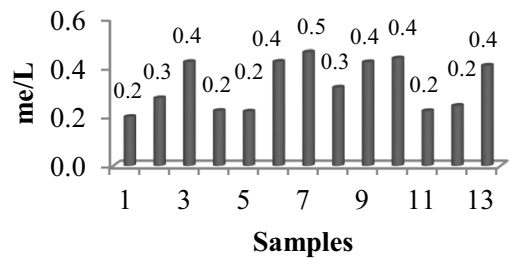

Na

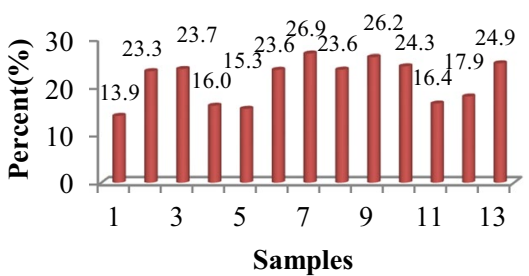

\begin{tabular}{|c|c|c|c|c|}
\hline$<20$ & $20-40$ & $40-60$ & $60-80$ & $>80$ \\
\hline Excellent & Good & Permissible & Doubtful & Unsuitable \\
\hline
\end{tabular}

RSC

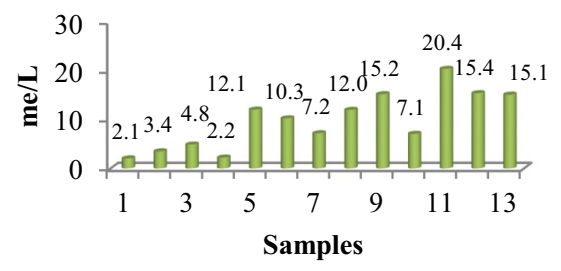

\begin{tabular}{|l|c|c|}
\hline$<1.25$ & $1.25-2.5$ & $>2.5$ \\
\hline Safe & Marginally suitable & Not suitable \\
\hline
\end{tabular}

MH

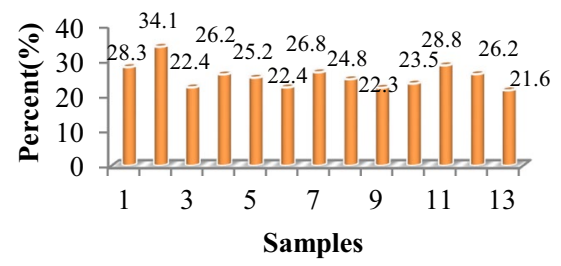

\begin{tabular}{|c|c|}
\hline$<50$ & $>50$ \\
\hline Suitable & Unsuitable \\
\hline
\end{tabular}
KR

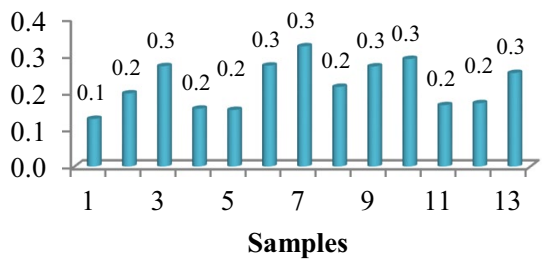

\begin{tabular}{|c|c|}
\hline$<1$ & $>1$ \\
\hline Suitable & Unsuitable \\
\hline
\end{tabular}

PI

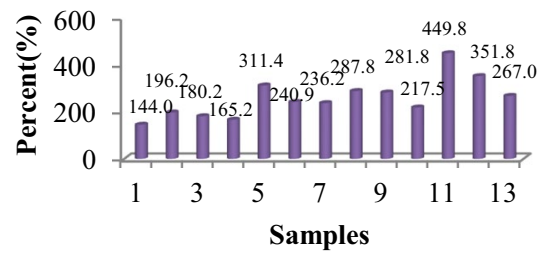

\begin{tabular}{|c|c|c|}
\hline$<25$ & $25-75$ & $>75$ \\
\hline Safe & Moderate & Unsafe \\
\hline
\end{tabular}

value $<1$ and are considered as suitable for irrigation since they contain less level of $\mathrm{Na}^{+}$.

The MH suggested for irrigation purpose depends on the concentration of calcium and magnesium which sustain a state of equilibrium in water (Houatmia et al. 2016). Excess concentration of magnesium in water during equilibrium will undesirably affect soil quality, resulting in a decrease in crop production (Kumar et al. 2007). In the analyzed wastewater samples, the MH values vary from 21.58 to 34.12 . All analyzed KWW samples, $\mathrm{MH}$ values $<50$ and hence are considered as harmless and suitable for irrigation use. The permeability of the soil is also affected by long-term use of irrigation water as it is influenced by calcium, sodium, magnesium, and bicarbonate content of the soil. The PI can help in evaluating the soil permeability that is affected by long-term use of irrigation water. It is found that PI values range from 143.97 to 449.79 which considered as unsuitable for irrigation use.
The SAR value of KWW samples ranges from 0.19 to 0.46 milliequivalent per liter (me/L) with an average value of $0.33 \mathrm{me} / \mathrm{L}$, while Ec ranges from 1397.01 to $12701.49 \mu \mathrm{S} / \mathrm{cm}$ with an average value of $5450.75 \mu \mathrm{S} / \mathrm{cm}$. High conductivity showed the presence of a higher concentration of dissolved salts and heavy metals due to washing of plates and utensils. From USSL classification, $30.77 \%$ of KWW samples fall in the $\mathrm{S}_{1} \mathrm{C}_{3}$ category. This category of wastewater may be used for irrigation in all types of soil with a slight danger of exchangeable sodium (Ostovari et al. 2015). Remaining wastewater quality $(69.23 \%)$ categorizes into the $\mathrm{S}_{1} \mathrm{C}_{4}$ category. Uncertainties prevail in USSL system in checking the final suitability of irrigation water as it does not mention anything about suitability for a combination of USSL class.

The fuzzy surface is a graphical representation that can be used to check the influence of SAR and Ec with the output score of KWW quality (Fig. 3). A nonlinear relationship has been observed between KWWIS and SAR, and Ec. At 


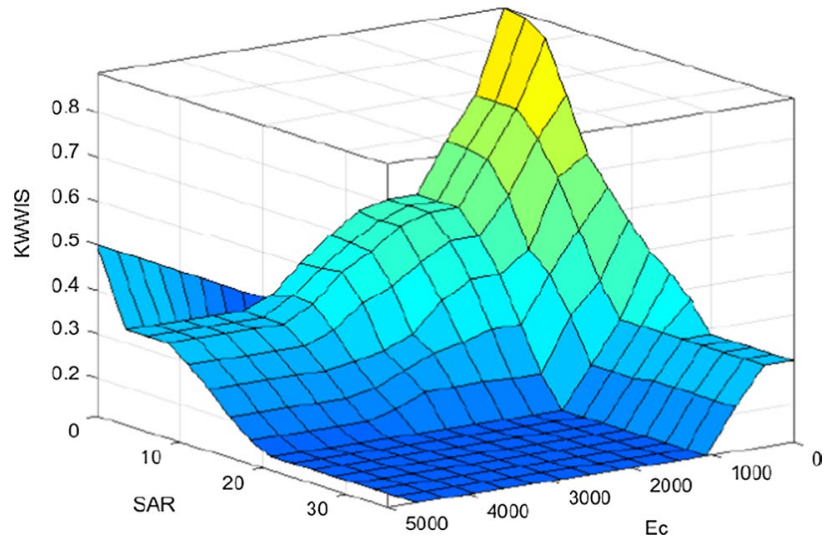

Fig. 3 Fuzzy surface: Ec and SAR versus KWWIS

higher values of SAR and Ec, the relationship with KWWIS becomes linear and flat, and the score tends to zero, considering "very bad" water quality. To have "very good" water for irrigation, score must be greater than 0.7 ; it can only be possible when SAR value $<10 \mathrm{me} / \mathrm{L}$ and Ec value $<250 \mu \mathrm{S} /$ $\mathrm{cm}$. Mirabbasi et al. (2008) and Ostovari et al. (2015) obtained a similar fuzzy surface with identical rules. The SAR values were always found less than $10 \mathrm{me} / \mathrm{L}$, whereas Ec was found exceeding $250 \mu \mathrm{S} / \mathrm{cm}$. The output of MFIS showed $92.31 \%$ medium and $7.69 \%$ bad class of sample category. In the present study, overall agreement between USSL and MFIS was 55.6\%, whereas Ostovari et al. (2015) and Mirabbasi et al. (2008) found $92.8 \%$ and $84 \%$, respectively. Ostovari et al. (2015) suggested with the rise of SAR and Ec concentration, USSL diagram failed to provide the correct classification of irrigation quality of groundwater that can be used for irrigation. Mirabbasi et al. (2008) revealed that in groundwater samples, maximum agreement was between USSL diagram and MFIS method with low SAR and Ec values.

\section{Impacts of raw kitchen wastewater on the environment}

The KWW contains higher concentration of various parameters as compared to irrigation standards (FAO 1994) and discharge to inland surface waters and discharge to public sewer (IS: 2490 (Part I) 1981) as shown in Table 3. Therefore, proper treatment is required before its discharge to avoid any environmental pollution. In developing countries like India, there is no separate drainage system for KWW. The pollutant present in KWW mixes with a common drain which finally discharges to water bodies like river, canals, and ponds. The presence of excess nutrients stimulates the growth of algae (eutrophication) which then decomposes, depletes oxygen level, and harms aquatic life (Raychaudhuri et al. 2014). Arsenic and mercury are not degraded easily and accumulate in fish tissues and enter the food chain. On consuming contaminated fish, human being faces serious health issues like the central nervous system, neurological impairment, kidney problem, etc. Higher phosphorus levels in the water body such as rivers cause eutrophication and depletion of dissolved oxygen level (Davie 2003).

Due to rich in nutrient, KWW can be a good option to counter the present freshwater stress for irrigation. Without any treatment of KWW, if it uses for irrigation, then it has an adverse effect both on crop and land. Higher TDS concentration in KWW hampers the efficiency of irrigation by clogging of irrigation systems and deposits layer on the inner side of pipes thus reducing the flow of water. High concentration of soluble salts like bicarbonate and sulfate creates white scale formation on leaves or fruit when sprinklers are used. The deposit on leaves or fruit reduces the marketability of fruit and foliage. Potassium also has the deleterious effect on soil hydraulic conductivity property apart from flora and fauna (Smith et al. 2014). In rural areas, KWW disposes of either in a small pit or drain on an open surface. The turbidity of KWW is high; it percolates slowly through the different layers of soil strata. After a certain period, the upper surface of the soil will be choked by tiny particles present in KWW. The stagnant KWW invites many diseases caused by mosquitoes like malaria, filariasis, and dengue. The wastewater contamination is more in shallow groundwater condition particularly in rainy season, causing diarrhea diseases.

In an urban area, most of the time KWW contaminates the freshwater by leakage in the water supply or groundwater contamination in rural areas due to its low groundwater level below the surface. Supply water pipe should be in good condition so that there should not be any crossconnection or leakage between freshwater and effluent (Drechsel et al. 2010). If KWW accidentally contaminates freshwater supply, then excess concentration of sulfate will cause laxative effect and gastrointestinal irritation, aluminum (Alzheimer's disease, neurological disorders,), copper (mucosal irritation, liver damage, depression, and renal damage), and zinc (gastrointestinal, abdominal pain, dehydration, nausea, and dizziness) (Raychaudhuri et al. 2014). A higher TDS concentration causes a dangerous effect to human health such as paralysis of the tongue, lips, and face, irritability, and dizziness (Gupta et al. 2017). In the human body, the reaction of nitrite and iron in red blood cell creates methemoglobin which stops oxygen level and thus causes a disease called blue baby syndrome. A higher value of turbidity reduces filter runs which cause harmful microorganisms to be more dangerous to human life. A higher phosphate concentration causes muscle damage, breathing problem, and kidney failure (Nyamangara et al. 2013; Gupta et al. 2017).

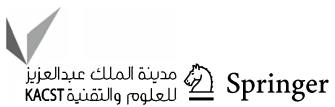




\section{Conclusion}

KWW with zero value can be considered as a valuable resource after exploring the hidden characteristics contained in it. In this study, to identify the possibilities for reusing of KWW in irrigation, KWW samples were examined in the laboratory. It was found that parameters like $\mathrm{pH}$, chloride, iron, copper, magnesium, lead, nickel, sodium, calcium, zinc, aluminum, and SAR are within permissible limit, while bicarbonate, total dissolved solid, conductivity, sulfate, and potassium have exceeded the permissible limit according to FAO. The result obtained from the USSL classification system suggested that $30.77 \%$ of KWW samples are safe for irrigation. The quality of KWW was observed to be safe for irrigation based on SAR, Na\%, KR, and $\mathrm{MH}$ indexes. But, for RSC and PI indexes, the KWW needs to be treated for sustainable reuse. After comparing USSL with MFIS, the overall agreement was found to be $55.6 \%$. From the obtained results, it was found KWW treatment is required to reuse in irrigation. To find a low-cost technique for KWW treatment is the future scope.

Acknowledgements This study is a part of $\mathrm{PhD}$ work. The authors would like to express their sincere gratitude and thanks to staff members of Environmental Engineering Laboratory of Civil Engineering Department of National Institute of Technology, Rourkela, for their help and assistance during laboratory analysis.

\section{Compliance with ethical standards}

Conflict of interest The authors declare that there is no conflict of interests regarding the publication of this manuscript. In addition, the ethical issues including plagiarism, informed consent, misconduct, data fabrication and/or falsification, double publication and/or submission, and redundancy have been completely observed by the authors.

Open Access This article is licensed under a Creative Commons Attribution 4.0 International License, which permits use, sharing, adaptation, distribution and reproduction in any medium or format, as long as you give appropriate credit to the original author(s) and the source, provide a link to the Creative Commons licence, and indicate if changes were made. The images or other third party material in this article are included in the article's Creative Commons licence, unless indicated otherwise in a credit line to the material. If material is not included in the article's Creative Commons licence and your intended use is not permitted by statutory regulation or exceeds the permitted use, you will need to obtain permission directly from the copyright holder. To view a copy of this licence, visit http://creativecommons.org/licenses/by/4.0/.

\section{References}

Abegunrin TP, Awe GO, Idowu DO, Onigbogi OO, Onofua OE (2013) Effect of kitchen wastewater irrigation on soil properties and growth of cucumber (Cucumis sativus). J Soil Sci Environ Manage 4(7):139-145
Abubakar S, Latiff AAA, Lawal IM, Jagaba AH (2016) Aerobic treatment of kitchen wastewater using sequence batch reactor (SBR) and reuse for irrigation landscape purposes. Am J Eng Res 5(5):23-31

Alavi N, Nozari V, Mazloumzadeh SM, Nezamabadi-pour H (2010) Irrigation water quality evaluation using adaptive network-based fuzzy inference system. Paddy Water Environ 8:259-266

Al-Hamaiedeh H, Bino M (2010) Effect of treated grey water reuse in irrigation on soil and plants. Desalination 256:115-119

Al-Jayyousi OR (2003) Gray water reuse: towards sustainable water management. Desalination 156(1-3):181-192

Amiri V, Rezaei M, Sohrabi N (2014) Groundwater quality assessment using entropy weighted water quality index (EWQI) in Lenjanat, Iran. Environ Earth Sci 72:3479-3490

APHA (2012) Standard methods for the examination of water and wastewater, 22nd edn. American Washington (DC) public health association, Washington

BIS:11624 (1986 Reaffirmed 2006) Indian standard guidelines for the quality of irrigation water. Bureau of Indian Standards Manak Bhavan 9 Bahadur Shah Zafar Marg New Delhi

Chandekar N, Godboley BJ (2017) A review on phytoremediation a sustainable solution for treatment of kitchen wastewater. Int J Sci Res 6(2):1850-1855

Davie T (2003) Fundamental of hydrology. Routledge Taylor and Francis Group, London and New York

Drechsel P, Scott C, Raschid-Sally L, Redwood M, Bahri A (2010) Wastewater irrigation and health: assessing and mitigating risk in low-income countries. International water management institute and international development research centre, Battaramulla

FAO (1994) Water quality for agriculture. Irrigation and drainage paper 29, M-56

Gharibi H, Mahvi AH, Nabizadeh R, Arabalibeik H, Yunesian M, Sowlat MH (2012) A novel approach in water quality assessment based on fuzzy logic. J Environ Manage 112:87-95

Ghosh S, Bhattacharya P, Majumdar S, Dasgupta S, Bandyopadhyay S (2010) Comparative studies on treatment of kitchen sink waste water using single and multichannel ceramic membrane. Int J Environ Technol Manage 13:336-347

Gupta A, Nath JR (2018) Kitchen greywater treatment in a constructed wetland microcosm using aquatic macrophytes. In: Singh VP et al (eds) Water quality management. Springer, Singapore

Gupta N, Pandey P, Hussain J (2017) Effect of physicochemical and biological parameters on the quality of river water of Narmada, Madhya Pradesh, India. Water Sci 31:11-23

Halliwell D, Barlow K, Nash D (2001) A review of the effects of wastewater sodium on soil physical properties and their implications for irrigation systems. Aust J Soil Res 39:1259-1267

Houatmia F, Azouzi R, Charef A, Bedir M (2016) Assessment of groundwater quality for irrigation and drinking purposes and identification of hydrogeochemical mechanisms evolution in Northeastern, Tunisia. Environ Earth Sci 75:746

Hussain I, Raschid L, Hanjra MA, Marikar F, Hoek WVD (2002) Wastewater use in agriculture: review of impacts and methodological issues in valuing impacts (with an extended list of bibliographical references). Working Paper 37 Colombo, International Water Management Institute, Sri Lanka

IS: 2490 Part 1 (1981) Indian standard for tolerance limits for industrial effluents

Jimenez B (2006) Special feature on groundwater management and policy, irrigation in developing countries using wastewater. Int Rev Environ Strategy 6(2):229-250

Jimenez B, Asano T (2008) Water reuse: An International survey of current practice, issues and needs. International Water Association Publishing, London 
Jowitt PW, Lumbers JP (1982) Water quality objectives, discharge standards and fuzzy logic. Proc Exeter Symposium IAHS 135:241-250

Katam K, Bhattacharyya D (2018) Comparative study on treatment of kitchen wastewater using a mixed microalgal culture and an aerobic bacterial culture: kinetic evaluation and FAME analysis. Environ Sci Pollut Res 25(21):20732-20742. https://doi.org/10.1007/ s11356-018-2209-6

Kelly WP (1963) Use of saline irrigation water. Soil Sci 95(4):355-391

Khan TM, Khalid A, Habib U, Ramay MI, Ali U, Samad N (2011) Aerobic treatment for recycling kitchen wastewater. Int J Agric Appl Sci 3(1):1-8

Kizhisseri MI, Mohamed MMA (2016) Fuzzy-based wastewater quality indices for pollution classification: a case study in the United Arab Emirates. Environ Syst Decis 36:62-71

Kumar M, Kumari K, Ramanathan AL, Saxena R (2007) A comparative evaluation of groundwater suitability for irrigation and drinking purposes in two intensively cultivated districts of Punjab, India. Environ Geol 53(3):553-574

Mirabbasi R, Mazloumzadeh SM, Rahnama MB (2008) Evaluation of irrigation water quality using fuzzy logic. Res J Environ Sci 2:340-352. https://doi.org/10.3923/rjes.2008.340.352

Mohamed RMSR, Chan CM, Ghani HB, Yasin MAM, Kassim AHM (2013) Application of peat filter media in treating kitchen waste water. Int J Zero Waste Gener 1(1):11-16

Mohamed RMSR, Al-gheethi A, Welfrad AN, Hashim MKA (2018) Development in-house: a trap method for pretreatment of fat, oil, and grease in kitchen wastewater. In: Hussain C (ed) Handbook of environmental materials management. Springer, Berlin

Nagaraju A, Thejaswi A, Sharifi Z (2016) Assessment of groundwater quality and its suitability for agricultural usage in and around Rangampeta Area, Andhra Pradesh, South India. J Water Chem Technol 38(6):358-365

Naserisafavi N, Chu MY (2017) Evaluation of kitchen wastewater with additives. Int Proc Chem Bio Environ Eng 102:57-64

Nyamangara J, Jeke N, Rurinda J (2013) Long term nitrate and phosphate loading river water in the upper Manyame catchment, Zimbabwe. Water SA 39(5):637-642

Ostovari Y, Beigi-Harchegani H, Asgari K (2015) A fuzzy logic approach for assessment and mapping of groundwater irrigation quality: a case study of Marvdasht aquifer, Iran. Arch Agron Soil Sci 61(5):711-723

Parwin R, Paul KK (2018) Treatment of kitchen wastewater using Eichhornia crassipes. In: Proceedings of the 1st international conference on civil and environment, vol 34, Universiti Malaysia Perlis, Arau, Malaysia, p 02033

Parwin R, Paul KK (2019a) Phytoremediation of kitchen wastewater using Eichhornia crassipes. J Environ Eng. https://doi. org/10.1061/(ASCE)EE.1943-7870.0001520

Parwin R, Paul KK (2019b) Efficiency of Eichhornia crassipes in the treatment of raw kitchen wastewater. SN Appl Sci 1(4):381. https ://doi.org/10.1007/s42452-019-0400-0

Parwin R, Paul KK (2020) Overview of applications of kitchen wastewater and its treatment. J Hazardous Toxic Radioact Waste. https ://doi.org/10.1061/(asce)hz.2153-5515.0000482

Parwin R, Jha R, Paul KK (2017) A novel approach for sub-basin wise water resources Assessment. Int J Innovat Res Sci Eng Technol 6(1):375-386. https://doi.org/10.15680/IJIRSET.2017.0601071

Priya KL (2013) A fuzzy logic approach for irrigation water quality assessment: a case study of karunya watershed, India. J Hydrogeol Hydrol Eng 2(1):1-8
Qadir M, Wichelns D, Raschid-Sally L, Minhas PS, Drechsel P, Bahri A, McCornick P (2007) Agricultural use of marginal quality water-opportunities and challenges. In: Water for food, water for life. A comprehensive assessment of water management in agriculture London, United Kingdom: Earthscan. https://hdl.handl e.net/20.500.11766/8359

Rahmat SN, Ali AZM, Ibrahim MHW, Alias NA et al (2017) Oil and grease $(\mathrm{O} \& \mathrm{G})$ removal from commercial kitchen waste water using carbonised grass as a key media. In: Hasan A (ed) Proceedings of the MATEC web conference, vol 87. Universiti Malaysia Sarawak, Sarawak

Ravikumar P, Somashekar RK (2014) Spatial distribution of macronutrients in soils of Markandeya river basin, Belgaum(d), Karnataka(s), India. Proc Int Acad Ecol Environ Sci 4(2):81-94

Raychaudhuri M, Raychaudhuri S, Jena SK, Kumar A, Srivastava RC (2014) WQI to monitor water quality for irrigation and potable use. DWM Bulletin No 71 directorate of water management Bhubaneswar India 43p

Richards LA (1954) Diagnosis and improvement of saline and alkali soils. Agri Hand book 60 US Dept of Agriculture Washington DC 160

Scott CA, Faruqui NI, Raschid-Sally L (2004) Wastewater use in irrigated agriculture: confronting the livelihood and environmental realities. CABI Publishing Wallingford, Wallingford

Shakir E, Zahraw Z, Al-Obaidy AHMJ (2017) Environmental and health risks associated with reuse of wastewater for irrigation. Egypt J Pet 26:95-102

Sivarajah S, Gnanavelrajah N (2015) Potential to grow selected leafy vegetables in kitchen wastewater hydroponics. Am Eurasian J Agric Environ Sci 15(12):2337-2342

Smith CJ, Oster JD, Sposito G (2014) Potassium and magnesium in irrigation water quality assessment. Agric Water Manage 157(7):59-64

Sridharan M, Nathan DS (2017) Groundwater quality assessment for domestic and agriculture purposes in Puducherry region. Appl Water Sci 7:4037-4053. https://doi.org/10.1007/s1320 1-017-0556-y

Srinivas R, Singh AP (2017) Development of a comprehensive fuzzy based approach for evaluating sustainability and self-purifying capacity of river Ganges. ISH J Hydraul Eng. https://doi. org/10.1080/09715010.2017.1400407

USSL (1954) Diagnosis and improvement of saline and alkali soils. United States development agency handbook 60. Government Printing Office, Washington, DC, p 147

Vakil KA, Sharma MK, Bhatia A, Kazmi AA, Sarkar S (2014) Characterization of greywater in an Indian middle-class household and investigation of physicochemical treatment using electrocoagulation. Sep Purif Technol 130:160-166

Wilcox LV (1955) Classification and use of irrigation water. United States Department of Agriculture circular, vol 969, p 19

Zadeh LA (1965) Fuzzy sets. Inf Control 8:338-353

Publisher's Note Springer Nature remains neutral with regard to jurisdictional claims in published maps and institutional affiliations. 